\title{
Group II intron-ribosome association protects intron RNA from degradation
}

\author{
LYDIA M. CONTRERAS, ${ }^{1,2,3}$ TAO HUANG $^{2,4}$ CAROL LYN PIAZZA, ${ }^{2,5}$ DORIE SMITH, ${ }^{2,5}$ GUOSHENG QU, ${ }^{5}$ \\ GRANT GELDERMAN, ${ }^{1}$ JEFFREY P. POTRATZ, ${ }^{3}$ RICK RUSSELL, $^{3}$ and MARLENE BELFORT ${ }^{2,5,6}$ \\ ${ }^{1}$ Department of Chemical Engineering, University of Texas at Austin, Austin, Texas 78712-2100, USA \\ ${ }^{2}$ Wadsworth Center, New York State Department of Health, Albany, New York 12201-2002, USA \\ ${ }^{3}$ Department of Chemistry and Biochemistry, Institute for Cellular and Molecular Biology, University of Texas at Austin, Austin, \\ Texas 78712-2100, USA \\ ${ }^{4}$ SUNY Downstate Medical Center, University Hospital, Brooklyn, New York 11203, USA \\ ${ }^{5}$ Department of Biological Sciences, RNA Institute, University at Albany, SUNY, Albany, New York 12222, USA
}

\begin{abstract}
The influence of the cellular environment on the structures and properties of catalytic RNAs is not well understood, despite great interest in ribozyme function. Here we report on ribosome association of group II introns, which are ribozymes that are important because of their putative ancestry to spliceosomal introns and retrotransposons, their retromobility via an RNA intermediate, and their application as gene delivery agents. We show that group II intron RNA, in complex with the intron-encoded protein from the native Lactoccocus lactis host, associates strongly with ribosomes in vivo. Ribosomes have little effect on intron ribozyme activities; rather, the association with host ribosomes protects the intron RNA against degradation by RNase E, an enzyme previously shown to be a silencer of retromobility in Escherichia coli. The ribosome interacts strongly with the intron, exerting protective effects in vivo and in vitro, as demonstrated by genetic and biochemical experiments. These results are consistent with the ribosome influencing the integrity of catalytic RNAs in bacteria in the face of degradative nucleases that regulate intron mobility.
\end{abstract}

Keywords: group II intron; ribonucleoprotein purification; ribosome protection; RNase E cleavage

\section{INTRODUCTION}

Group II introns are mobile retroelements that self-splice and insert either site-specifically into allelic intron-less DNA or less specifically at ectopic sites, minimally impairing gene function (Lambowitz and Belfort 1993; Bonen and Vogel 2001; Belfort et al. 2002; Pyle and Lambowitz 2006). Mobile group II introns are of evolutionary significance, being present in archaea, bacteria, and the organelles of eukaryotes, and they are hypothesized to be ancestral to eukaryotic retrotransposons and spliceosomal introns, and to the spliceosome itself (Belfort et al. 2002; Beauregard et al. 2008; Lambowitz and Zimmerly 2011; Galej et al. 2013). Furthermore, their ability to move within and likely between genomes makes them excellent candidates for applications in therapeutic gene targeting and genomic manipulation (Toro et al. 2007; Lambowitz and Zimmerly 2011).

During group II intron mobility, a highly stable ribonucleoprotein (RNP) complex forms between the intron RNA and the intron-encoded protein (IEP), where the protein

\footnotetext{
${ }^{6}$ Corresponding author

E-mail mbelfort@albany.edu

Article published online ahead of print. Article and publication date are at http://www.rnajournal.org/cgi/doi/10.1261/rna.039073.113.
}

and RNA associate with picomolar affinity and high specificity (Saldanha et al. 1999). RNP formation plays a critical role in facilitating intron targeting and invasion of the DNA substrate. With the model intron LtrB, from Lactoccocus lactis, mobility initiates when the IEP (LtrA) assists the folding of the intron RNA into a catalytically active structure that is capable of splicing and then integrating into target DNA (Mills et al. 1997; Cousineau et al. 1998). Intron splicing results in ligated exons and in a stable RNP consisting of the excised intron lariat and the IEP protein, in a ratio of 1 RNA:2 IEP (Saldanha et al. 1999; Wank et al. 1999; Huang et al. 2011). This RNP recognizes a DNA integration site in a highly site-specific way, using a combination of interactions based on protein recognition and base-pairing with the intron RNA. After integration into the dsDNA target, the RNP promotes reverse transcription of the inserted intron RNA (Lambowitz and Belfort 1993).

\footnotetext{
(C) 2013 Contreras et al. This article is distributed exclusively by the RNA Society for the first 12 months after the full-issue publication date (see http://rnajournal.cshlp.org/site/misc/terms.xhtml). After 12 months, it is available under a Creative Commons License (Attribution-NonCommercial 3.0 Unported), as described at http://creativecommons.org/licenses/by-nc/ $3.0 /$.
} 
Based on informatic, biochemical, and genetic studies, structure models of the $L$. lactis group II intron have revealed a complex, highly structured RNA secondary structure composed of six domains (Michel and Ferat 1995; Matsuura et al. 2001; Dai et al. 2008). An interesting feature of this structure is the mapping of the IEP binding site to a small region of domain IV that contains its own ribosome-binding site (RBS), comprising a Shine-Dalgarno sequence and initiation codon (Wank et al. 1999; Singh et al. 2002). Furthermore, binding of the IEP to domain IV down-regulates LtrA translation (Singh et al. 2002).

Data suggest that group II intron mobility depends on host genes and cellular factors and that group II intron activity may be coordinated with physiological processes that are of critical importance to the cell (Coros et al. 2008, 2009; Yao et al. 2013). However, given that most of our understanding of the RNP comes from in vitro self-assembly experiments and from genetic analyses, the potentially complex nature of the relationship of the intron RNP with its molecular environment remains unclear. Here, we report that native LtrB RNP particles from $L$. lactis associate strongly with host ribosomes in vivo and in vitro, an interaction that is consistent with intron splicing. We present biochemical and genetic experiments indicating that the ribosome protects the intron and its open reading frame (ORF) against RNase E degradation. These results are of interest in view of the silencing effect of RNase E on intron mobility (Coros et al. 2008) and suggest that ribozyme stability is enhanced by ribosome association.

\section{RESULTS}

\section{Isolation of RNP complexes from L. lactis reveal association with ribosomes}

Ribosome co-elution with the LtrB group II intron RNP from its native $L$. lactis host was first reported in the context of purification of an RNP precursor wherein the intron was trapped between two short exons by deleting the adenosine with its $2^{\prime}$ $\mathrm{OH}$ that initiates splicing $(\Delta \mathrm{A})$ (Huang et al. 2011). In the current study, active RNPs comprising the excised intron $(+\mathrm{A})$ were isolated and purified away from precursor particles using an inteinbased strategy (Fig. 1A). Again, we used a construct expressing the intron and LtrA in tandem, with LtrA fused to an intein and chitin binding domain (Huang et al. 2011). LtrA complexed with the intron was released from a chitin column by intein cleavage with the reducing agent DTT, and the RNP was separated on a sucrose density gradient. As for the $\triangle \mathrm{A}$ precursor, $16 \mathrm{~S}$ rRNA and to a lesser extent $23 \mathrm{~S}$ rRNA co-eluted with the intron RNA.

To rule out the possibility that ribosome association was a function of the RNP isolation method, a different purification scheme was designed to isolate RNPs from L. lactis. Briefly, a tandem affinity purification (TAP) tag was used to isolate RNP particles (Rigaut et al. 1999), where LtrA was tagged with a calmodulin binding tag that was separated from protein A by a TEV protease cleavage site (Fig. 1B). The RNP-protein
INTEIN BASED

$\mathbf{A}$
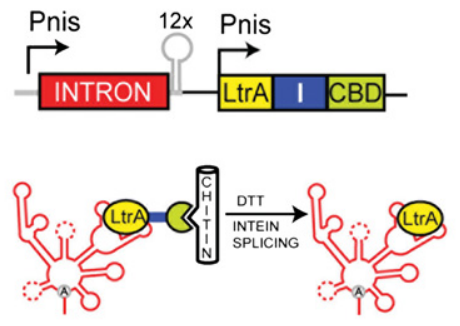

TAP TAG

B
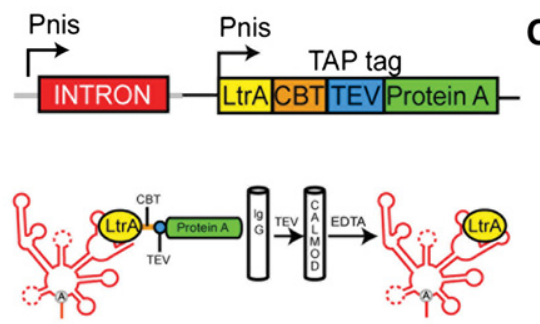

TAP TAG

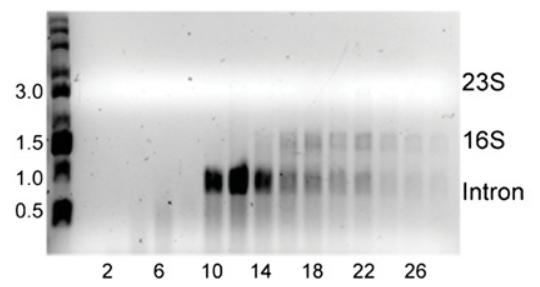

D

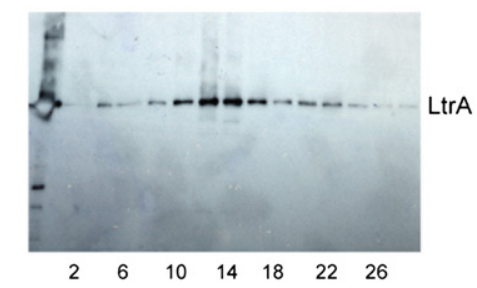

FIGURE 1. Intron RNP complexes from $L$. lactis associate with ribosomes. (A) Intein-based group II intron RNP isolation. (Left) Schematic of RNP (+A) purification via chitin binding domain. The exons contain 12MS2 tag, for separation in the sucrose gradient as described in the Materials and Methods. (Right) Sucrose gradient fractions. After purification on a chitin column, the RNPs were separated on sucrose gradients and run on a $1.2 \%$ denaturing formaldehyde Agarose gel. The first lane shows 0.5- to 10-kb RNA ladder. This gel corresponds to Northern and Western blots in panels $C$ and $D$, respectively. (B) TAP-tag group II intron isolation. (Top) Schematic of TAP-tag purification using tandem IgG-calmodulin columns. (Bottom) Gradient fractionation, which was as for the intein-based isolation. Copurification of $16 \mathrm{~S}$ rRNA is apparent, but $23 \mathrm{~S}$ rRNA is masked by a bleaching artifact. $(C)$ Northern blot of sucrose gradient fractions from an intein-based purification ( $\operatorname{panel} A$ ). Hybridization was with a $23 S$ probe, $16 \mathrm{~S}$ probe, and a group II intron probe. $(D)$ Western blot analysis of sucrose gradient samples in panel $A$ with polyclonal antibody raised to LtrA. 
A was eluted from an IgG column, treated with TEV, and the pure RNP eluted from a calmodulin column by chelating calcium with EDTA. Regardless of the type of purification used to isolate native RNP particles, we observed ribosome association with $\sim 50 \%$ of the intron $(44 \%-$ $69 \%$ ) over five different experiments, depending on the type of purification and experimental condition. Additionally, when passing purified intron-ribosome complexes over a second gradient, $>80 \%$ of intron RNPs remained bound to ribosomes.

The amount of $16 \mathrm{~S}$ rRNA observed exceeded that of $23 \mathrm{~S}$ (Fig. 1A,B), suggesting that binding was primarily via the $16 \mathrm{~S}$ rRNA. Primary binding of $16 \mathrm{~S}$ rRNA is supported by the observation that the 16S rRNA can be 10-fold more abundant than the 23S rRNA in the eluted fractions, whereas $16 \mathrm{~S}$ and 23S rRNA are present in similar amounts in the flowthrough fractions within a factor of 2 (Fig. 2A,B). The co-elution of the rRNAs was confirmed by Northern blotting for the intein-based chitin purification with probes for the intron, 16S, and $23 \mathrm{~S}$ RNAs (Fig. 1C). Additionally, anti-LtrA Western blot analysis confirmed LtrA protein co-elution with the intron RNA (Fig. 1D), reinforcing the idea that the intact intron RNP particle associates with ribosomes.

Although it seemed unlikely that ribosomes were binding to the different column matrices (Fig. 1A, chitin resin; Fig. 1B, Agarose-based resin), this was tested directly. The construct shown in Figure $1 \mathrm{~A}$ was modified by removing the ICBD tag to create an untagged RNP that should not bind to the resin. After using the standard intein-mediated purification scheme (Fig. 1A), we showed that $16 \mathrm{~S}$ and $23 \mathrm{~S}$ were only pulled down in the presence of the chitin-bound RNP (Supplemental Fig. 1A). Additional confirmation of intron RNP-ribosome complex formation in vivo was provided by ribosome purification from $L$. lactis cells overexpressing $+\mathrm{A}$ intron RNP construct (Fig. 1A), where intron RNA copurified with rRNA (Supplemental Fig. 1B).

To probe the tenacity of the RNP-ribosome association, we characterized the
A

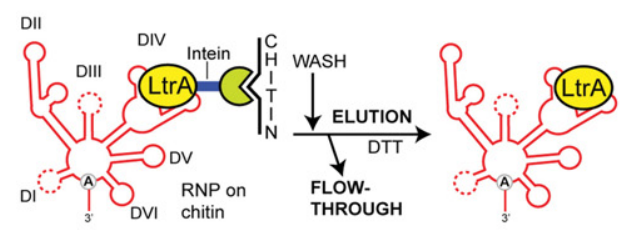

B

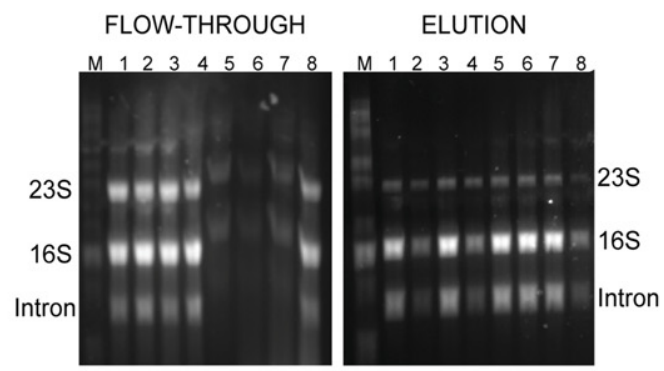

C

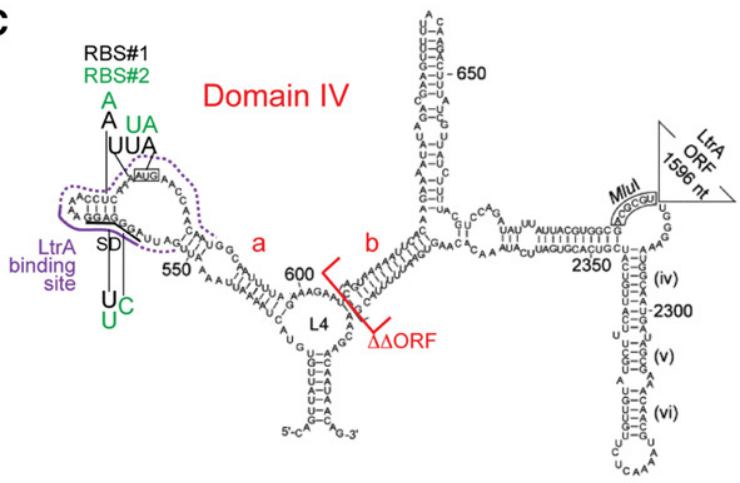

D

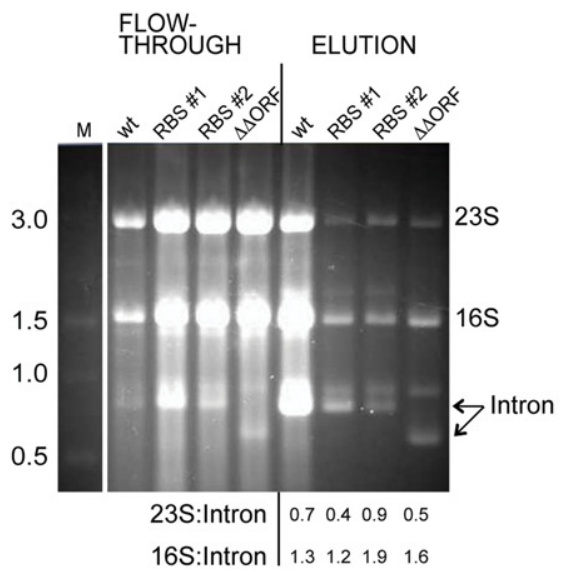

FIGURE 2. Ribosome association is resistant to stringent washes and mutations of RBS. $(A)$ Schematic of the intein-based RNP $(+\mathrm{A})$ purification, as in Figure 1A. Cell lysates were loaded onto $1-\mathrm{mL}$ chitin columns and washed under various stringent conditions. (B) Flow-through and elution samples were separated on a $1.2 \%$ denaturing formaldehyde Agarose gel. (Lane $M$ ) Marker; (lane 1) $0.5 \mathrm{M} \mathrm{NaCl}, 0.1 \% \mathrm{NP} 40$; (lane 2) $1 \mathrm{M} \mathrm{NaCl}, 0.1 \%$ NP40; (lane 3) $0.5 \mathrm{M} \mathrm{NaCl}$, 0.5\% NP40; (lane 4) $1 \mathrm{M} \mathrm{NaCl}, 0.5 \% \mathrm{NP} 40$; (lane 5) $1 \mathrm{M}\left(\mathrm{NH}_{4}\right)_{2} \mathrm{SO}_{4}, 0.1 \% \mathrm{NP} 40$; (lane 6) $1 \mathrm{M}$ $\left(\mathrm{NH}_{4}\right)_{2} \mathrm{SO}_{4}, 0.1 \% \mathrm{NP} 40,300 \mu \mathrm{g}$ tRNA; (lane 7) $1 \mathrm{M}\left(\mathrm{NH}_{4}\right)_{2} \mathrm{SO}_{4}, 0.1 \%$ NP40, $300 \mu \mathrm{g}$ tRNA, 7.5 $\mathrm{M}$ urea; (lane 8) $1.5 \mu \mathrm{g}$ RBS-specific oligonucleotide (IDT 2270), $300 \mu \mathrm{g}$ tRNA, $300 \mu \mathrm{g}$ GTP, $0.1 \%$ NP40. (C) Mutations in domain IV. Mutations for RBS\#1 are shown in green and those for RBS\#2 are shown in black. The section of DIV deleted in $\triangle \triangle$ ORF is bracketed in red. The approximate LtrA binding site is outlined in purple, with highly conserved residues marked by a solid line. Secondary structure diagrams here, and in Figures 5A and 7B, are from Cui et al. (2004). (D) Effect of intron mutants on elution and ribosome binding. Flow-through and elution samples were collected as in panel $B$ and separated on a 1.2\% denaturing formaldehyde Agarose gel. (Lane 1) Wild-type +A; (lane 2) mutants RBS\#1; (lane 3) RBS\#2; and (lane 4) $\Delta \Delta$ ORF. Approximate ratios of rRNA to intron are shown below (not normalized by differences in mass). 
flow-through and elution from the chitin affinity resin under various conditions (Fig. 2A). Washes included different salt concentrations (0.1-1 M NaCl; low salt to interrupt possible hydrophobic interactions, high salt to disrupt ionic interactions), various reducing agents to disrupt possible disulfide bonds, different pHs, detergents (NP40, SDS), ammonium sulfate, the denaturant urea, and tRNA to compete with the observed rRNA (some conditions are shown in Fig. 2B). None of these conditions were able to dislodge 16S rRNA from the intron, unless lengthy incubation with the stringent wash preceded elution. Significantly, the addition of a complementary oligonucleotide designed to the Shine-Dalgarno sequence of the ribosome binding site in the intron, aimed to destabilize any already-existing binding of the isolated intron to this region, also had no effect (Fig. 2B, lane 8). We also attempted different column sizes, resin concentrations, and loading conditions to evaluate potential saturation of our binding resin. Although different conditions affected the efficiency of the purification, the ratio of $16 \mathrm{~S}$ and $23 \mathrm{~S}$ rRNA to intron RNA remained high even under the harshest wash conditions (Fig. 2B).

\section{Disruption of RBS in the intron does not eliminate ribosome association}

We next wished to consider the potential contribution of the RBS toward ribosome binding. This question is particularly relevant given the overlap between the RBS and the binding site of the LtrA IEP in domain IVa (Fig. 2C). For these experiments, we constructed two point mutants (RBS\#1, RBS\#2) and a deletion mutant $(\triangle \triangle \mathrm{ORF})$. Briefly, the point mutants were designed to eliminate the RBS consensus without altering essential nucleotides for LtrA binding (Singh et al. 2002), while $\triangle \triangle$ ORF preserves the RBS in domain IVa but removes most of the ORF sequence and was constructed to assay the effect of the $5^{\prime}$ region of the ORF in this interaction. These mutations reduced the efficiency of group II intron binding, as evidenced by more material flowing through and less eluting with the mutants (Fig. 2D, lanes 2-4) relative to the parental construct (Fig. 2D, lane 1), likely because the mutations affect LtrA binding. Nevertheless, the ratios of 23S:intron RNA and 16S: intron RNA in the eluted fractions remained similar (Fig. 2D).

\section{In vitro binding assays to evaluate interactions with $30 S$ and 705 particles and binding specificity}

To evaluate the ability of the LtrB intron RNA alone to bind ribosomes, gel-shift assays were performed with purified 30S, 50S, and $70 \mathrm{~S}$ ribosome particles and group II intron RNA synthesized in vitro (Fig. 3A). The 955-nt transcript contained the 902-residue $+\mathrm{A}$ intron, plus 27- and 26-nt $5^{\prime}$ and $3^{\prime}$ flanking sequences, respectively. Both $70 \mathrm{~S}$ and $30 \mathrm{~S}$ particles bound the RNA prepared from a T7 promoter, but no $50 \mathrm{~S}$ subunit binding was observed. Figure $3 \mathrm{~A}$ shows representative data from RNA-70S and RNA-30S binding ex-
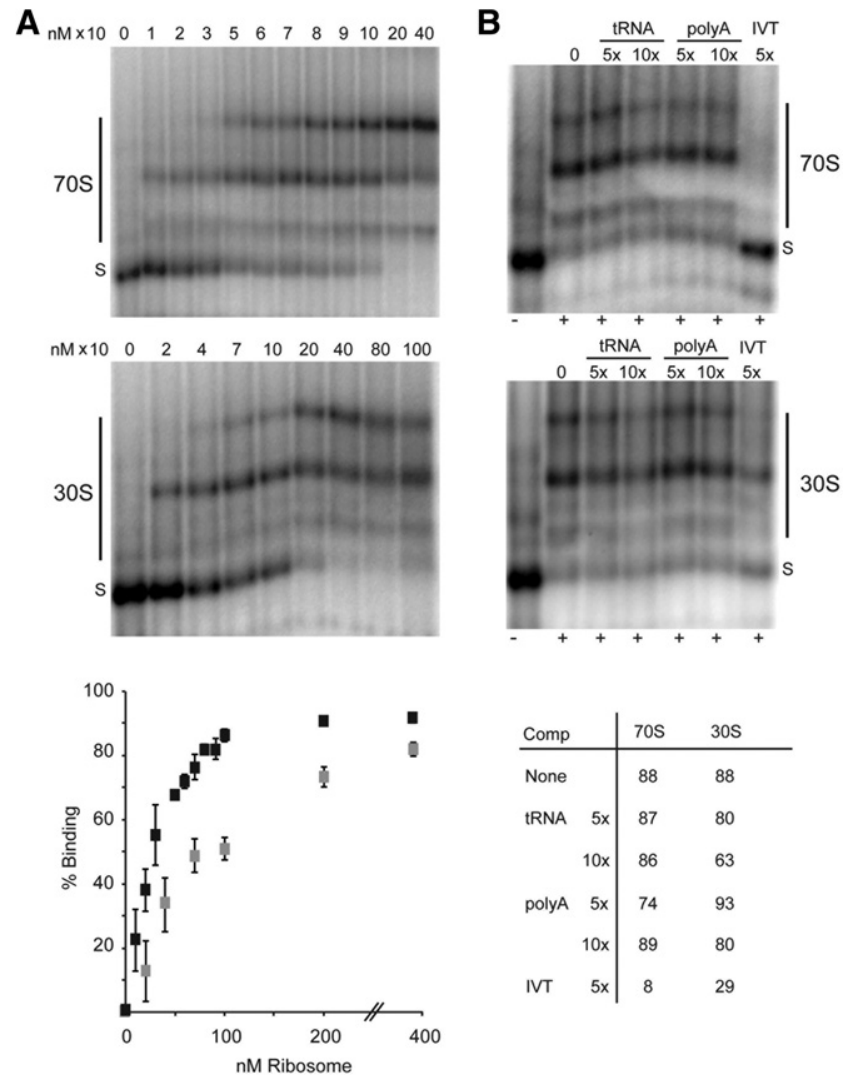

\begin{tabular}{lr|cc}
\multicolumn{2}{l|}{ Comp } & $70 \mathrm{~S}$ & $30 \mathrm{~S}$ \\
\hline None & & 88 & 88 \\
TRNA & $5 \times$ & 87 & 80 \\
& $10 \mathrm{x}$ & 86 & 63 \\
polyA & $5 \mathrm{x}$ & 74 & 93 \\
& $10 \mathrm{x}$ & 89 & 80 \\
IVT & $5 \mathrm{x}$ & 8 & 29
\end{tabular}

FIGURE 3. Ribosome binding to intron-containing RNA is specific. (A) Ribosome binding analysis. Intron pre-mRNA synthesized in vitro $(75 \mathrm{nM})$ was incubated in the absence or presence of $70 \mathrm{~S}$ (top) or $30 \mathrm{~S}$ (middle) ribosome particles. The RNA substrate (S) was shifted with increasing amounts of ribosome (vertical black bar). Ribosome concentrations are listed above each lane. The amount of shifted intron-containing RNA substrate with 70 S and 30 S ribosomes was plotted against the concentration of ribosomes (bottom). The 70S ribosome shift is shown in black squares, and the $30 \mathrm{~S}$ subunit shift is shown in gray squares with standard error shown for $n=3$. (B) Competition experiments. RNA binding experiments were performed as in panel $A$ with nonspecific RNA competitors, yeast tRNA ${ }^{\text {Phe }}$ and polyA, at fivefold and 10 -fold excess. A specific competitor (unlabeled in vitro transcript of the $+\mathrm{A}$ intron RNA) was used at fivefold excess. Ribosome concentrations used were $100 \mathrm{nM}$ for $70 \mathrm{~S}$ and $200 \mathrm{nM}$ for $30 \mathrm{~S}$. The table below shows percent binding for each condition.

periments, where refolded intron pre-mRNA (first lane) was allowed to bind different concentrations of $70 S$ ribosomes or $30 \mathrm{~S}$ subunits. The dissociation constant $\left(\mathrm{K}_{\mathrm{d}}\right)$ was $\sim 20 \mathrm{nM}$ for the interaction with the $70 \mathrm{~S}$ particle (Fig. $3 \mathrm{~A}$, bottom). This binding affinity is comparable to the strong association between ribosomes and translation factors during translation initiation (Marintchev and Wagner 2004). A higher $\mathrm{K}_{\mathrm{d}}$ of $\sim 80 \mathrm{nM}$ was determined for $30 \mathrm{~S}$ particles.

Specificity of the binding reaction was tested by competition with tRNA and polyA RNA (Fig. 3B). Binding of the 955-nt intron-containing transcript to the $70 \mathrm{~S}$ and $30 \mathrm{~S}$ particles was minimally affected by the presence of a fivefold or 10fold excess of the competitor RNA. In contrast, an unlabeled in vitro intron-containing transcript competed effectively with 
the radiolabeled RNA for $70 \mathrm{~S}$ and $30 \mathrm{~S}$ binding. Interestingly, there was some degree of competition of tRNA with the $30 \mathrm{~S}$ particle, consistent with tRNA binding sites on this subunit and with the lower affinity of the $30 \mathrm{~S}$ particle for the intron RNA.

For both the 70S and 30S particles, two distinct bands were initially observed, raising the possibility of different types of complexes forming between the intron RNA and ribosomal particles (Fig. 3A). The presence of $16 \mathrm{~S}$ rRNA was confirmed in the shifted bands by Northern blot analysis (data not shown). Different stoichiometric ratios, splicing status, or RNA conformation are all possibilities to account for multiple bands, which did not change in the presence of nonspecific inhibitors (Fig. 3B). Importantly, these experiments show that ribosomes bind specifically to the intron RNA and that the $70 S$ ribosome has an approximately fourfold higher affinity for the intron pre-mRNA than the 30S subunit. Further, these results suggest that these associations can be independent of any cellular factors or the presence of the IEP.

These in vitro binding experiments raised the question of the ability of RNA alone to recruit ribosomes in vivo, in the absence of the IEP. Although intron RNA expressed in vivo and purified from cells was consistently degraded in experiments in which MS2-tagged intron RNA was isolated in the absence of the IEP, $16 \mathrm{~S}$ and, to a lesser extent, $23 \mathrm{~S}$ rRNA co-eluted with the fragmented intron RNA (data not shown). In contrast, when the LtrA protein was isolated from cells in the absence of intron RNA, no co-elution of the ribosome was detected, suggesting that the intron RNA was indeed recruiting rRNA in the cell.

\section{Association with ribosomal RNA is consistent with RNP activity}

Ribosome binding to group II intron RNP particles prompted us to investigate how this association affects the biological activity of the intron. Sucrose gradient fractions containing rRNA-bound RNPs were compared with intron-only fractions for binding in electrophoretic mobility shift assays (EMSA) and DNA integration activity assays. Even-numbered fractions (Fig. 4A, top) were profiled by EMSA with an oligonucleotide duplex DNA that contains the intron homing site (Fig. 4A, middle). The amounts of intron RNA, 16S rRNA, and RNP DNA complexes were quantitated and their distributions plotted (Fig. 4A, bottom). To compare the relative binding activity, EMSA was performed on pooled fractions 12-14 (pure intron) and 20-23 (16S rRNA-associated intron) (Fig. 4B, left). Binding activity of the $16 \mathrm{~S}$ rRNA-associated intron was 1.2 relative to the free intron when normalized to the amount of intron in the complex, as tabulated below the figure.

DNA integration activity assays were also performed with pooled sucrose-gradient fractions containing native RNP-ribosome complexes formed in vivo, on an internally labeled DNA-homing site target. Relative levels of intron integration

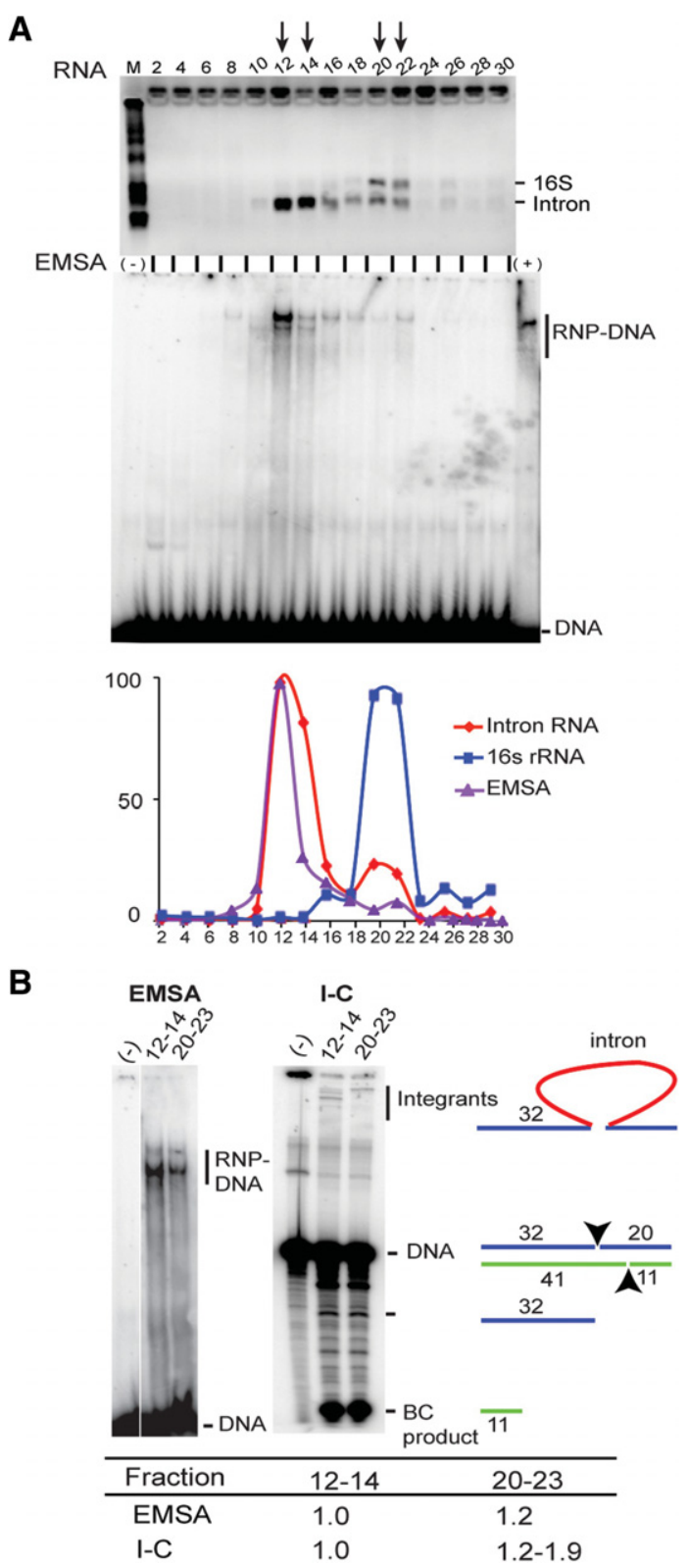

FIGURE 4. Association with rRNA is consistent with group II intron RNP activity. (A) DNA binding of sucrose gradient fractions. After intein-based purification, fractionation of RNPs on a sucrose gradient (Fig. 1A) was followed by separation of RNA on a 1.2\% Agarose-formaldehyde gel (top). Peak fractions of pure intron (12-14) and intron with rRNA (20-22) are marked with arrows. These gradient fractions were tested for DNA binding by electrophoretic mobility shift analysis (EMSA, middle). The shifted bands (RNP-DNA) were quantitated and plotted against intron and 16S rRNA from the top panel, as represented in the graph (bottom). (B) DNA binding and integration activity of pooled sucrose gradient fractions. Peak intron fractions without (1214) and with (20-23) rRNA were assayed for DNA binding by EMSA (left), and integration into and cleavage of labeled DNA target (I-C; right). A schematic of the integration/cleavage assay is on the right of the acrylamide gel, with substrate and products shown alongside gel bands. The amount of RNP-DNA determined by EMSA and integration and cleavage products (I-C) for rRNA bound RNPs is indicated in the table, relative to free intron RNP. The values in fractions 20-23 are normalized to the amount of intron in the complex. 
and bottom strand cleavage products (I-C) were normalized to the levels present with pure intron RNA (Fig. 4B, right). The activity ranged from 1.2 for the integrants to 1.9 for the bottom-strand cleavage product for the rRNA-associated intron (fractions 20-23), relative to the free intron RNP (fractions 12-14). Integration assays were also performed with complexes assembled in vitro by prebinding purified RNPs and ribosomes, under conditions where most RNPs are ribosome-bound. Again, samples containing ribosomes were as active as the free RNPs (data not shown). Together these data show no detectable interference in the ability of the RNP to properly assemble into a catalytically active complex and to recognize and act on its DNA target.

\section{S ribosome subunits alter RNP structure, exposing nucleotides in domains I and IV}

To understand the effect of $30 \mathrm{~S}$ subunit binding on the local conformation of the RNP, we probed the free RNP and the $\mathrm{RNP}+30 \mathrm{~S}$ ribosome complex with dimethyl sulfate (DMS), to determine which adenine and cytosine residues were exposed to the aqueous environment. Footprinting was conducted by reverse transcription of the DMS-treated RNP complexes to probe DMS methylation at adenine-N1 and cystidine-N3, which block cDNA synthesis. We focused on $30 \mathrm{~S}$ subunit binding given that the 16S rRNA-RNP binding was the predominant association observed in this study. By comparing a reverse transcriptase extension of specific primers in DMS-treated RNP, DMS-treated RNP+30S, untreated RNP, and untreated RNP+30S, we determined that $30 \mathrm{~S}$ association resulted in a reproducible and significant increase in DMS modifications of selected adenosine and cytidine nucleotides relative to the group II intron RNP alone. Figure 5 shows representative gels and interpretative diagrams, where nucleotides that gave at least 1.5 -fold greater DMS reactivity in the RNA+30S sample are indicated in red (ratios less than 1.5 were also observed but are not reported here). These sites of enhanced methylation by DMS are concentrated in domains I ( $5^{\prime}$ stem-loops) and IV and are likely the result of changes in the folded state of the intron caused by the $30 \mathrm{~S}$ ribosome

A

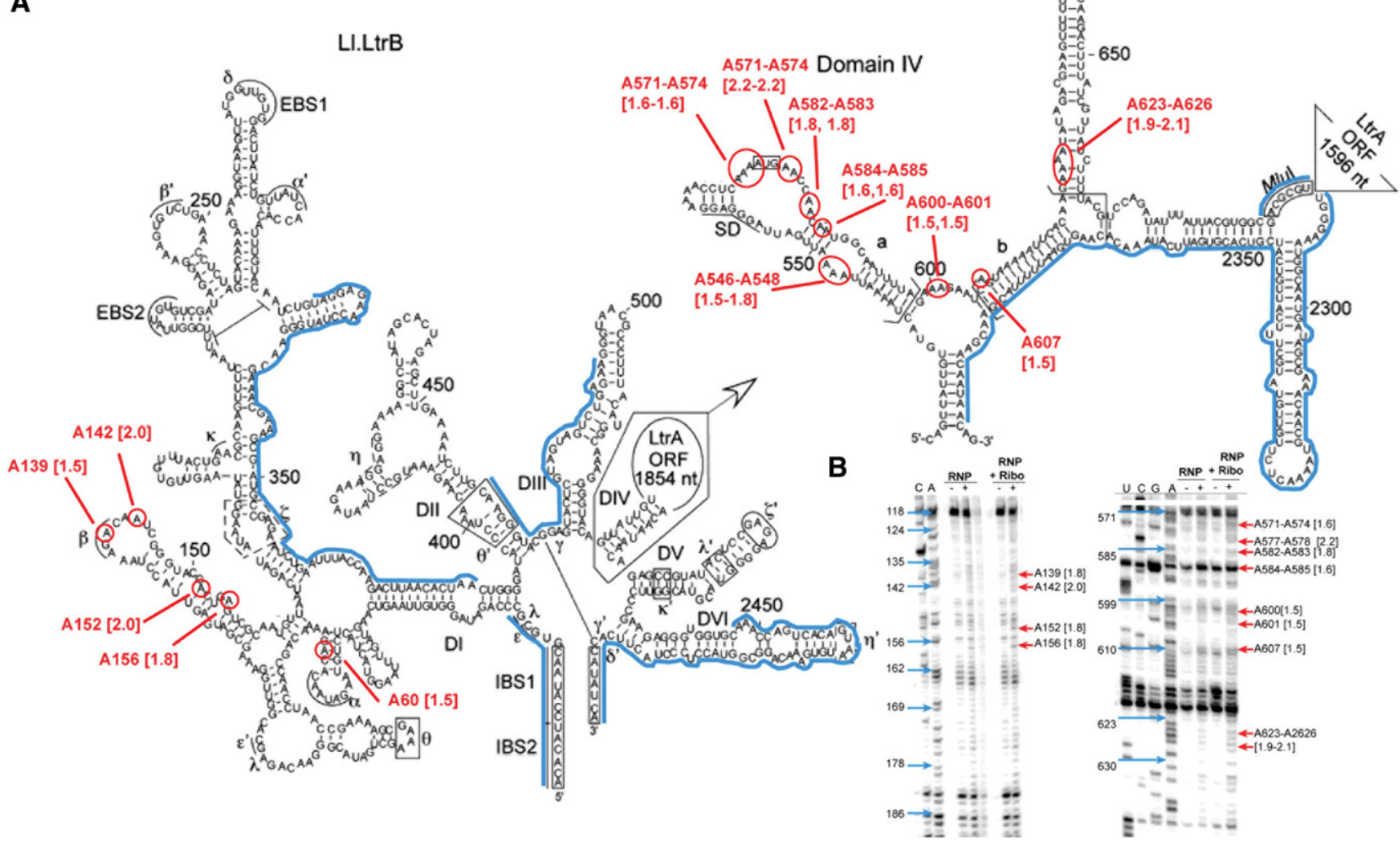

FIGURE 5. Binding of 30 S ribosomes impacts domains I and IV of the group II intron. (A) Map of the group II intron with location of exposure to DMS methylation. Nucleotides circled in red, numbered from position 1 of the intron, exhibited increased exposure to DMS methylation after binding the $30 \mathrm{~S}$ ribosome, with representative data in panel $B$. The number in brackets refers to an increase in band intensity caused by the binding of the $30 S$ particle relative to the RNP alone, with multiple numbers referring to different nucleotide positions. Blue lines represent areas that were not probed due to difficulties in reverse transcription of that region. (B) Representative reverse transcription analysis of the group II intron after DMS methylation. Reverse transcription was on RNP and RNP+30S samples that were either treated with DMS (+) or not treated with DMS $(-)$, separated alongside A, C, G, or U sequencing lanes. Positions found to be differentially methylated by DMS are marked by red arrows and labeled as in panel $A$. 
A

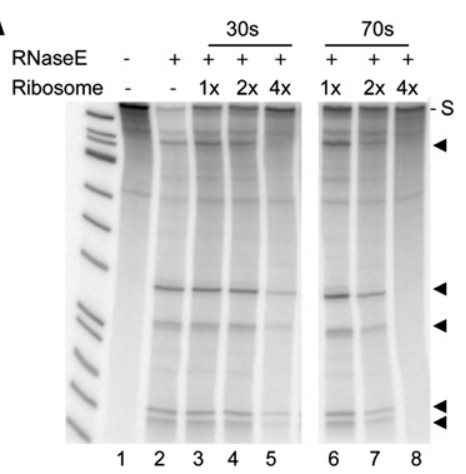

B

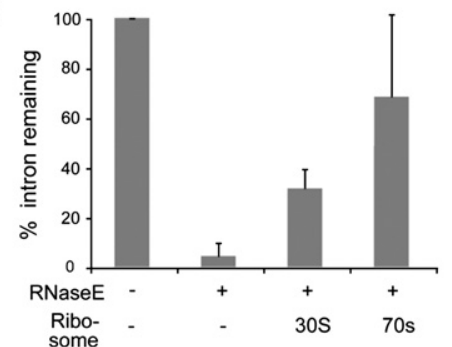

FIGURE 6. Ribosomes protect the group II intron against RNase E cleavage. (A) RNase E cleavage and protection by ribosomes. Intron RNA synthesized in vitro was incubated in the absence (lane 1) or presence (lanes 2-8) of RNase E, after complexing with 30 S (lanes 3-5) or 70 S (lanes 68 ) ribosome particles. These were present at one-, two-, or fourfold molar excess, as indicated. After $30 \mathrm{~min}$, Ambion $2 \times$ gel load dye was added, and samples were separated on a $5 \%$ denaturing gel. S represents substrate RNA; black triangles represent cleavage bands. (B) Quantitation of RNase E cleavage and protection by ribosomes. The amount of intact intron was quantitated from lanes $1,2,5$, and 8 by using phosphorimaging and ImageQuant software 5.2 and plotted. The data plotted in the bar graph represent data from three independent experiments.

particle. The presence of enhancements and the lack of protections are contrary to changes in DMS reactivity that typically arise as result of RNA-protein complex formation. However, previous DMS footprinting analysis of the association of the ribosome with a pseudoknot structure also indicates the potential for enhanced modifications resulting from enhanced nucleoside exposure (Mazauric et al. 2009).

\section{Ribosomes protect the group II intron against RNase E cleavage}

We next performed cleavage experiments with RNase E to achieve a footprint of the ribosome on the intron. This approach was inspired by genetic and biochemical experiments that previously showed that group II intron mobility is subject to silencing by RNase E degradation (Smith et al. 2005; Coros et al. 2008). We therefore hypothesized that the presence of ribosomes could affect intron degradation by RNase E. RNase E is a $5^{\prime}$-endoribonuclease that is known to have preferences for certain RNA sequences such as A-U-rich single-stranded RNA regions (Carpousis 2007). We first incubated labeled group II intron RNA with $30 \mathrm{~S}$ or $70 \mathrm{~S}$ ribosome particles, and then treated the complexes with purified RNase E. The en-

zyme cleaved the intron, resulting in bands of discrete size (Fig. $6 \mathrm{~A}$ ), while a control inactive RNase E mutant (D303R) was unable to digest the group II intron RNA (data not shown). The $30 \mathrm{~S}$ and $70 \mathrm{~S}$ particles both substantially protected the intron RNA from cleavage, resulting in persistence of the full-length intron, and fainter cleavage products (Fig. 6B). Although we have not eliminated the possibility that ribosomes inhibit RNase E activity rather than RNA access, the end-result would be similar, namely, a protective effect of ribosomes on intron degradation. Moreover, protection by $70 \mathrm{~S}$ ribosomes always exceeded that by $30 S$ particles.

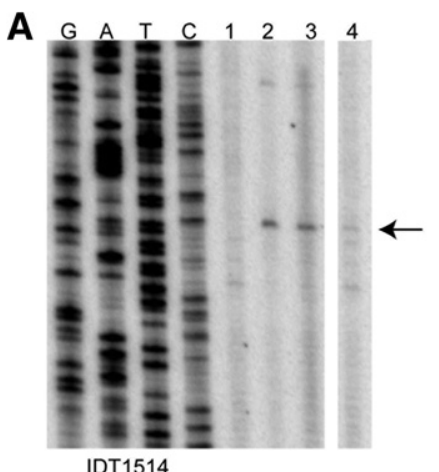

IDT1514

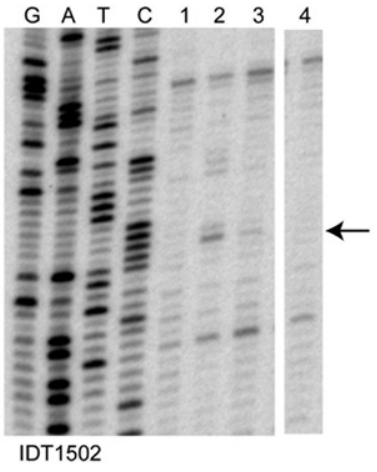

B

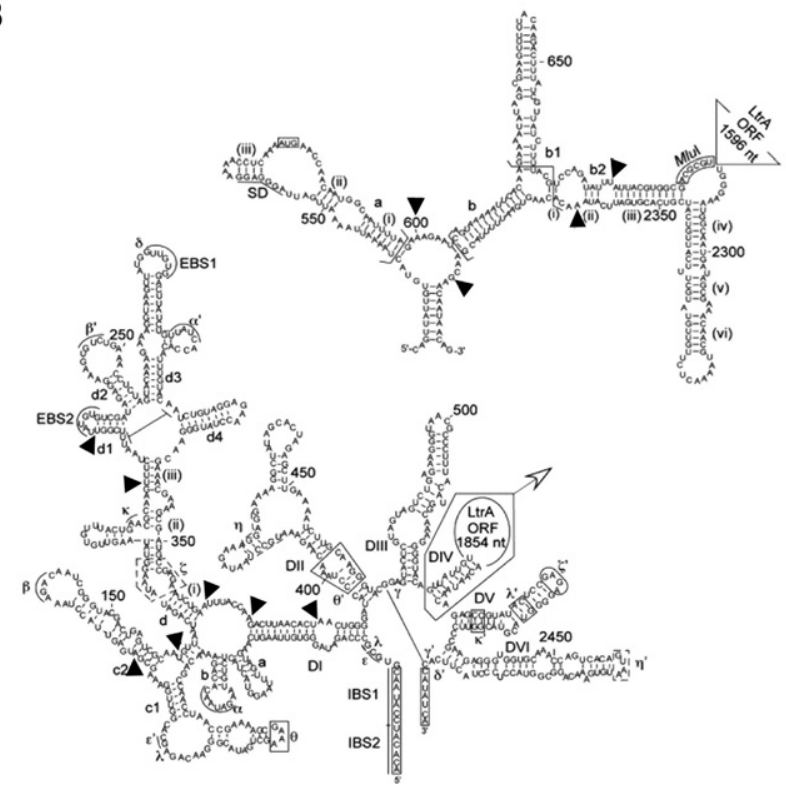

FIGURE 7. RNase E cleavage sites map to domains I and IV. (A) Mapping of RNase E cleavage sites. Representative data are given for primer extension analysis of RNase E cleaved intron with primers IDT1514 and IDT1502. Reactions were uncleaved (lane 1) or cleaved with RNase $\mathrm{E}$ in the absence of ribosomes (lane 2) or with $30 \mathrm{~S}$ (lane 3 ) or $70 \mathrm{~S}$ particles (lane 4). RNase E cleavages are indicated by arrows where protection by $70 \mathrm{~S}$ ribosomes and, to some extent, by $30 \mathrm{~S}$ subunits is apparent. (B) RNase E cleavage sites. RNase E cleavages mapped using primers $\sim 100 \mathrm{nt}$ apart that span the intron (Supplemental Table 2) were used to identify cleavage/protections sites as in panel $A$. These sites are shown by black triangles on the group II intron structure. Domain VI could not be analyzed because of primer binding. 
To map specific cleavage sites, intron RNA that had or had not been pre-incubated with $30 \mathrm{~S}$ or $70 \mathrm{~S}$ ribosomes was incubated with RNase E and used for primer-extension analysis with probes priming $\sim 100 \mathrm{nt}$ apart around the entire intron sequence (Fig. 7A,B). It was found that domains I and IV presented RNase E cleavage sites, in contrast to domains II, III, and V (domain VI could not be analyzed because of primer binding) and that all these sites were protected by ribosome binding. Similar experiments were performed with group II intron RNPs purified from L. lactis. Some RNase E cleavage sites correspond exactly to the cleavages on in vitro synthesized RNA, but others were shifted by a few nucleotides. Importantly, corresponding sites were protected in fractions containing 16S rRNA. Moreover, the correlation of the RNase E footprints to the results with DMS methylation, where domains I and IV specifically were affected by $30 \mathrm{~S}$ ribosome binding, suggests that intron domains I and IV are the primary regions of interaction with rRNA. Given the structural changes that are detected in the RNP upon ribosome binding (Fig. 5), protection against RNase E (Figs. 6, 7) could result either from direct binding of the ribosome around the cleavage sites or from structural changes in the RNA that prevent access of the enzyme to the sites.

\section{Intron mobility decreases in ribosome assembly mutants and is rescued by a defective RNase $E$}

Given that intron activity in vitro was not greatly perturbed by the association with ribosomes, we wished to explore the effect of ribosomes on intron movement in vivo. We therefore measured mobility frequency in Escherichia coli mutants with defective ribosome assembly that decrease intracellular $70 \mathrm{~S}$ pools. Retrotransposition (RTP) assays were performed according to the method previously described (Coros et al. 2005; Beauregard et al. 2006) in an rbfA mutant strain, in which cellular concentrations of $30 \mathrm{~S}$ and $50 \mathrm{~S}$ subunits increase relative to $70 \mathrm{~S}$ ribosomes (Inoue et al. 2003; Xia et al. 2003). Using a retromobility indicator gene (RIG) as an intron donor, we are able to measure retromobility by selection for kanamycin resistance. Intron mobility was compromised an average of approximately fivefold with defective ribosome assembly in the $r b f A$ mutant relative to the wild type (Fig. 8A). One possible explanation for these results is that in this strain the IEP, required for intron retromobility, is not being properly synthesized. However, Western blot analysis of soluble cellular extract showed that the IEP is expressed in the rbfA strain at levels comparable to the wild-type strain (data not shown). An alternative hypothesis is that RNase E-mediated cellular degradation of the intron RNA increases with a defective $70 \mathrm{~S}$ ribosome pool. This idea is supported by previous observations that intron mobility is favored in the absence of cellular RNase E (Smith et al. 2005; Coros et al. 2008) and is consistent with results obtained in these studies with the same rne mutant strain (Fig. 8A). To test this hypothesis, a double mutant $r b f A$ rne

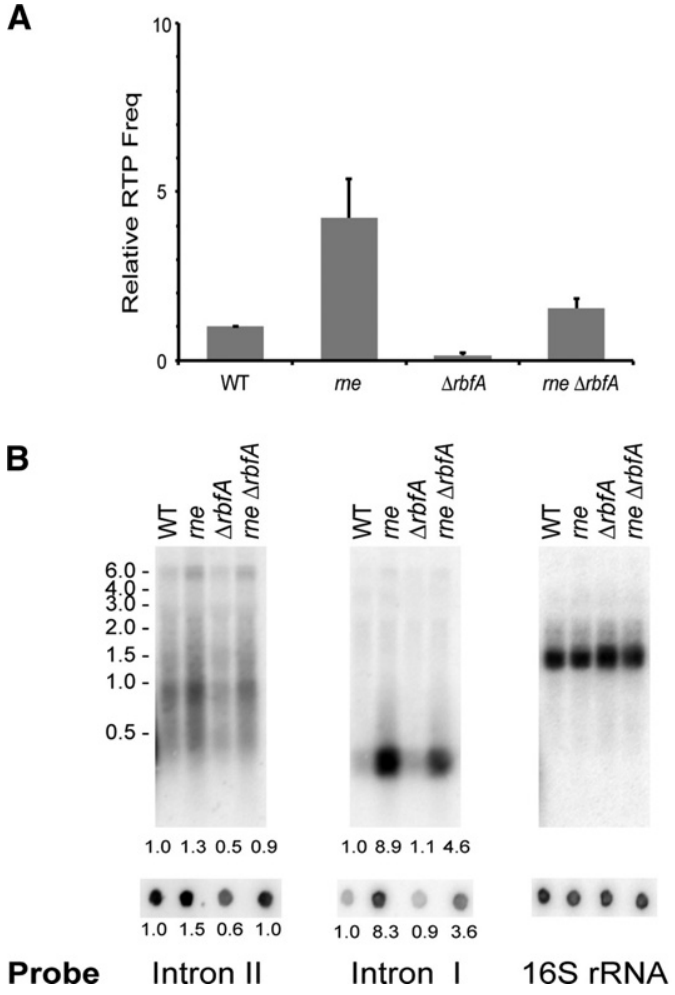

FIGURE 8. Intron mobility, RNase E activity, and ribosome assembly. (A) Retrotransposition frequencies in Escherichia coli mutants with defective ribosome assembly. Intron mobility was measured in E. coli using a retrotransposition indicator gene (RIG) with selection for Kan ${ }^{\mathrm{R}}$. Frequencies relative to the wild type are shown. $N=7$. (B) RNA levels by hybridization. Northern blots and dot blots were performed with RNA extracted from strains in panel $A$. Intron probes were against the group II intron itself (intron II), the group I intron contained within the group II intron in the donor plasmid (intron I), and 16S rRNA. Values are normalized to the level of $16 \mathrm{~S}$ rRNA and expressed relative to the wild-type strain for both the Northern and dot blots.

was constructed, and retromobility and intron RNA levels were measured in $r b f A$, rne, and $r b f A$ rne backgrounds. Whereas in the rne mutant alone, RTP was enhanced about fourfold relative to the isogenic wild-type strain and RTP dropped about fivefold in the $\triangle r b f A$ mutant, intron inheritance rose to exceed wild-type levels in the $\triangle r b f A$ rne double mutant (Fig. 8A). The observation that RTP levels are restored in the double-mutant strain suggests that the effect of ribosomes on intron activity is dependent on the presence of RNase E.

Intron RNA levels were measured in these same genetic backgrounds with intron probes in both Northern hybridization and dot blots (Fig. 8B). A probe to both the group II intron itself (II) and the group I intron that resides within the group II intron (I) in the RIG donor were used because the latter probe gives a sharper hybridization signal (Coros et al. 2008). The data were normalized to the level of $16 \mathrm{~S}$ rRNA. Considering both the intron probes, we note that whereas group II intron RNA levels fell by up to $50 \%$ in the $\triangle r b f A$ mutant, they increased up to eightfold in the rne mutant and 
about fourfold in the rbfA rne double mutant, with a more clear-cut result for the intron I probe. The more dramatic overall result in the genetic experiment (Fig. 8A) than in the hybridization assays (Fig. 8B) is likely attributable to the increased sensitivity of the RTP measurements, where readout is a completed retromobility event. In contrast, hybridization detects both intact RNA and partially degraded RNA that is nonfunctional. Importantly, RNA levels were restored to at least wild-type levels in the $r f b A$ rne double mutant irrespective of intron probe, consistent with ribosome association with the group II intron affording protection against RNase E degradation.

\section{DISCUSSION}

In this work, we report that the native LtrB group II intron associates strongly with $70 \mathrm{~S}$ and $30 \mathrm{~S}$ ribosome particles primarily through contacts in domain I and domain IV of the intron. Surprisingly, this interaction is compatible with intron activity; rather, we discovered that the interaction protects the group II intron RNA against RNase E cleavage and prevents intron degradation. Domain I is an independent folding scaffold for group II introns (Qin and Pyle 1997), and its association with rRNA appears consistent with the domain's role in intron folding, substrate binding, reaction specificity, and catalysis (Pyle and Lambowitz 2006). In contrast, domain IV is not an integral part of the intron structure but rather is predicted to protrude away from the core structure (Wank et al. 1999; Huang et al. 2003; Dai et al. 2008), where rRNA binding is again compatible with group II intron catalysis.

Approximately one-half of the total group II intron RNP was isolated in complex with rRNA (Fig. 1). Given the tenacity of the rRNA-intron association (Fig. 2), it is likely that two distinct populations of RNPs coexist naturally, one rRNAfree and one rRNA-bound. However, we have not eliminated the possibility that most RNPs are rRNA-bound in cells and that isolation of rRNA-free RNPs occurs as a result of dissociation during purification. Although interactions of the group II intron are strongest with $70 \mathrm{~S}$ particles, affinity to the $30 \mathrm{~S}$ particle is also high (Fig. 3), and 16S rRNA is the predominant species to copurify with the intron RNA (Figs. 1, 2). It is unclear if the group II intron RNP-70S complexes are predominant in vivo but unstable to purification or if $30 \mathrm{~S}$ complexes also exist in vivo. Regardless, the biological significance of the interaction is evident from genetic experiments in which defects in ribosome assembly greatly reduce the ability of the group II intron to retrotranspose (Fig. 8).

The protection of mRNA transcripts from RNase E by ribosomes in bacteria has been widely reported (Dreyfus 2009). However, a role in protecting an untranslated RNA like the group II intron catalytic core was surprising. It is therefore of interest that a predominant binding site for the ribosome occurs in domain IVa of the intron (Figs. 5, 7), a region surrounding the native RBS of the intron-encoded LtrA protein. It is possible that binding at the RBS provides the mechanism to protect the intron as well as the transcript that encodes the LtrA protein required for mobility. Domain IVa also contains the LtrA binding site that overlaps the RBS, with LtrA down-regulating its own translation (Singh et al. 2002). Although, $16 \mathrm{~S}$ rRNA binding to the group II intron was maintained when the RBS was mutated, the RBS mutations were subtle and designed to be compensatory (Fig. 2C) to maintain LtrA binding and RNP formation. When we blocked the RBS with complementary oligonucleotides, in vitro binding of ribosomes was substantially reduced (data not shown). Other regions of the intron, in domains I and IV, also likely serve as interaction sites. The RBS-LtrA binding region is clearly the focus of multiple layers of regulation and possibly the reason that LtrA is also expressed from its own independent transcript (Zhou et al. 2000). It is also noteworthy that residues in domain IVa are highly conserved in LtrA, in particular amino acid residues 81PQ82 (Dai et al. 2003). These amino acids map to the same region cleaved by RNase E. Protection of such a highly conserved region raises the possibility that other ORF-encoding introns may be similarly protected by ribosomes from RNase degradation.

Another consideration is the potential binding of ribosomes (or rRNA) to domain I of the intron. This domain forms a substantial fraction of the folded group II intron surface and would therefore be readily available for interactions. Domain I is transcribed and folded first and buttresses the conformation of downstream segments of the intron (Qin and Pyle 1997; Pyle et al. 2007). The presence of ribosome-protected RNase E sites in domain I could therefore imply another type of regulation, at the level of the folding of the ribozyme, consistent with regulation of intron mobility in vivo.

The protective effect of ribosomes against RNase E degradation was demonstrated both in vitro (Figs. 6, 7) and in vivo (Fig. 8), where reducing RNase E levels suppressed the RTP defects in ribosome assembly mutants. Given the association of this endoribonuclease with the degradasome in bacteria and the fact that enolase, a key player in bacterial metabolism, is a component of the degradasome (Carpousis 2007), it would not be surprising if the group II intron RNP-rRNA interaction helps synchronize intron activity with the nutritional state of the cell. The effects of RNase $\mathrm{E}$ deficiency and degradasome formation on nutrient utilization in E. coli (Tamura et al. 2013) further support an interplay between RTP and the metabolic status of the cell. Another interesting feature of this network of interactions is the ability of the degradasome to form a stable complex with the ribosome and polysomes (Tsai et al. 2012). Collectively, RNase E silencing of group II intron RTP (Smith et al. 2005; Coros et al. 2008; Yao et al. 2013), the ribosome-intron interaction in vitro (Fig. 3A), blockage of RNase E cleavage on the ribozyme (Figs. 6, 7), and nutritional sensing by the degradasome (Carpousis 2007; Tamura et al. 2013) strengthen the argument that this RNase E-ribosome-group II intron "interactome" keeps group II intron movement in tune with cellular metabolism. 
The association of ribosomes with other large catalytic RNAs has been previously observed and has been linked to interesting biological functions. As an example, the Tetrahymena group I intron is associated with $50 \mathrm{~S}$ ribosomes, suggesting that group I introns could inhibit protein synthesis, thereby causing cellular toxicity (Nikolcheva and Woodson 1997). A second example involves the interaction of RNase $\mathrm{P}$ with $30 \mathrm{~S}$ ribosomes, where speculations include the role of the ribosome in increasing RNase $\mathrm{P}$ specificity and also acting as a regulator of cell growth (Barrera and Pan 2004). The evolutionary relationship between introns and the ribosome is further underscored by the large number of introns that are found within rRNAs (Jackson et al. 2002).

The precise role of the group II intron-ribosome association remains to be determined in the context of the diverse biological functions of these RNA catalysts. These studies will be of fundamental mechanistic importance and be relevant to the technological interest in controlling intron activity in cells for various gene targeting applications.

\section{MATERIALS AND METHODS}

\section{Media and bacterial strains}

L. lactis IL1403 was used for RNP expression and for ribosome purification and was grown in M17 broth (BD Difco no. 218561) plus $0.5 \%$ glucose. RTP assays in E. coli were done in LB broth (BD Difco no. 244620) in strains derived from MC1061(DE3). MC1061(DE3) rne::Tn5 was created by P1 transduction using MC1061(DE3) dedEHS rne::Tn5 lysate (Coros et al. 2008) and was confirmed by PCR using primers IDT532 and IDT363. MC1061(DE3) $\Delta r b f A$ and MC1061(DE3) rne::Tn5 $\Delta r b f A$ were created using the $\lambda$ Red disruption system. A PCR reaction to amplify the cat $\left(\mathrm{Cam}^{r}\right)$ gene and the FRT (FLP recognition target) site from plasmid pKD3 was done with oligonucleotides containing homology to $r b f A$, IDT2994 and IDT2995. The product was transformed into a pKD46-containing (Red recombinase expression plasmid) strain, BW25113 (Datsenko and Wanner 2000). Mutated genes were then transferred into MC1061(DE3) strains via P1 transduction. Strains were confirmed by PCR using primers IDT3003 and IDT3004.

\section{Plasmids}

Full plasmid names, references, and their use are listed in Supplemental Table 1. The plasmid used for expression of the RNP for intein-based purification was pLtrB $\Delta$ ORF12MS2-LIC, abbreviated to $\mathrm{p}+\mathrm{A}$. This construct is a derivative of the $+\mathrm{A}$ construct (Huang et al. 2011) and includes a 12MS2 tag in the exons that allows for further purification of the RNP. With the addition of MBPMS2, precursor RNP complex increases in size and is more easily separated in the sucrose gradient. For TAP, the plasmid used for expression of the RNP was pLtrB $\triangle$ ORF-LtrA-TAP, abbreviated to $p$ $+\mathrm{A}$-TAP. Intron mutant derivative of $\mathrm{p}+\mathrm{A}, \mathrm{p} \Delta \Delta \mathrm{ORF}$, contains the RBS and the start codon of the LtrA IEP but has a deletion of the rest of the ORF (187 bp removed) (Fig. 2C). Plasmid $\mathrm{p} \Delta \Delta \mathrm{ORF}$ was created by SOEing (splicing by overlap extension) (Horton et al. 1990) and cloned first into Zero Blunt TOPO vector
(Invitrogen Kit \#450245) and then into p+A (digested with XhoI and AatII to remove the WT intron). For SOEing, the first round of two PCRs included products made with primers IDT1561/ IDT2923 and IDT1562/IDT2924 using p+A-LtrA (intein-less derivative of $\mathrm{p}+\mathrm{A}$ ) as a template. Next, a second round of two PCR products were created with primers IDT1561/IDT2925 and IDT1562/ IDT2926 using the respective PCR products from round one as templates. One last PCR was done by SOEing and used equimolar amounts of the PCR products from the second round of PCR as template with primers IDT1561 and IDT1562. The mutants were confirmed by sequencing with IDT1562.

RBS point mutants are as follows: RBS\#1 (pRBS\#1) - p+A with intron mutations A560U, U569A, AAU 573-575 UUA, and RBS\#2 (pRBS\#2) - $\mathrm{p}+\mathrm{A}$ plasmid with intron mutations G558C, A560U, U569A, AU 574-575 UA. They were created using Stratagene Quikchange Site-Directed Mutagenisis Kit according to the manufacturer's protocol.

RTP assays were done using pET-TORF/RIG (Coros et al. 2005). For in vitro transcription of the intron, the template was produced by PCR using plasmid $\mathrm{p}+\mathrm{A}-\mathrm{L}$ trA.

\section{RNP purification}

For the intein-based purification, IL1403 cells containing p+A were grown, and the RNP was purified on a chitin column and fractionated from a sucrose gradient, as described for the $\Delta \mathrm{A}$ construct (Huang et al. 2011). Cells were lysed with lysozyme, freeze/thaw, and sonication and then centrifuged at 10,000 RPM for $25 \mathrm{~min}$ in an F-34-6-38 rotor. A portion of the sucrose gradient fractions were phenol/chloroform extracted twice, ethanol precipitated, resuspended in formaldehyde load dye (Ambion), and separated on a 1.2\% Agarose/formaldehyde gel.

For RNP TAP-tag purification, cell growth and preparation of IL1403 containing $\mathrm{p}+\mathrm{A}$-TAP were performed as for the inteinbased construct. Cell lysate was incubated at $4^{\circ} \mathrm{C}$ tumbling with IgG-Sepharose beads (GE Healthcare) prewashed with Column Buffer $100\left(\mathrm{CB}_{100}\right)$ (20 mM Tris- $\mathrm{HCl}$ at $\mathrm{pH} 8.0,100 \mathrm{mM} \mathrm{NaCl}$, $0.1 \mathrm{mM}$ EDTA, $0.1 \% \mathrm{NP}-40)$. The IgG beads were washed three times with $10 \mathrm{~mL} \mathrm{CB}_{100}$ and then with $10 \mathrm{~mL}$ TEV cleavage buffer $\left(\mathrm{CB}_{100}+1 \mathrm{mM}\right.$ DTT $)$. The TAP tag was cleaved using 100 units of TEV protease (Invitrogen) in $400 \mu \mathrm{L}$ of TEV cleavage buffer for 2$3 \mathrm{~h}$ at $16^{\circ} \mathrm{C}$. The eluate was then loaded onto a $5 \%-20 \%$ sucrose gradient in $40 \mathrm{mM}$ Tris- $\mathrm{HCl}(\mathrm{pH} 7.5), 100 \mathrm{mM} \mathrm{NaCl}$, and 5 $\mathrm{mM} \mathrm{MgCl}_{2}$ and ultracentrifuged in a SW41 rotor (Beckman Coulter) for $16 \mathrm{~h}$ at $4^{\circ} \mathrm{C}$ at $27,000 \mathrm{rpm}$. Sucrose gradient fractions were separated on a gel as was done for the intein-based purification.

For intein-based RNP purifications with stringent wash conditions, cell growth and preparation of IL1403 containing p+A were performed as for the intein-based construct. Cell lysate was loaded onto 1-mL chitin columns (New England BioLabs no. S6651L, BioRad no. 731-1550) equilibrated with Column Buffer 500 $\left(\mathrm{CB}_{500}\right)(0.5 \mathrm{~m} \mathrm{NaCl}, 0.1 \% \mathrm{NP} 40,20 \mathrm{mM}$ Tris at $\mathrm{pH} 8.0,0.1 \mathrm{mM}$ EDTA). The chitin was washed with 20 column volumes (CV) of $\mathrm{CB}_{500}$, treated with $10 \mathrm{CV}$ of a specified stringent wash buffer, and then washed again with $20 \mathrm{CV}$ of $\mathrm{CB}_{500}$. Finally, the columns were washed with three $\mathrm{CV}$ of $\mathrm{CB}_{500}+40 \mathrm{mM}$ DTT and incubated overnight for cleavage of the intein. To elute, the columns were washed with $5 \mathrm{CV}$ of $\mathrm{CB}_{500}$. 
Stringent wash buffers are as specified in Figure 2 (legend). Flowthrough and eluate samples were processed and separated on a gel as was done for the intein-based purification.

For intein-based RNP purification of intron mutants RBS\#l, RBS\#2, and $\triangle \triangle O R F$, cell growth and preparation of IL1403, containing the corresponding plasmid constructs, were performed as for the intein-based construct. Purifications were performed as for the stringent wash conditions, except the columns were washed only with $\mathrm{CB}_{500}$. Flow-through and eluate fractions were collected, concentrated using Amicon ultra-15 centrifugal filter units (MWCO: $50 \mathrm{kDa}$, Millipore), and separated on a gel, as was done for the intein-based purification. RNA levels were quantitated with BioRad ChemiDoc Quantity One software.

\section{Northern blot analysis}

For analysis of RNP purification sucrose gradient fractions, RNA samples separated on an Agarose/formaldehyde gel were transferred to GE Healthcare Amersham Hybond-N membrane, UV crosslinked, and hybridized with GE Healthcare Rapid-Hyb Buffer, according to the manufacturer's protocol for oligonucleotide probes. The membrane was hybridized for detection of $23 \mathrm{~S}$ rRNA, $16 \mathrm{~S}$ rRNA, and group II intron with ${ }^{32} \mathrm{P}$-labeled oligonucleotides IDT889, IDT861, and IDT1073, respectively; exposed on a phosphor screen; and developed on a Typhoon Trio.

For analysis of RTP, total RNA was prepared from cultures using Qiagen RNeasy Mini Kit and separated on an Agarose/formaldehyde gel. Northern blotting was performed as above, and the membrane was hybridized for detection of group II intron, $t d$ group I intron (within the TORF-RIG donor plasmid), and 16S rRNA using ${ }^{32} \mathrm{P}-\mathrm{la}-$ beled oligonucleotides IDT653, MB14, and IDT861, respectively. RNA levels were analyzed using Image Quant 5.2 software.

\section{Western blot analysis}

For analysis of LtrA in the RNP purification, $30 \mu \mathrm{L}$ of RNP purification sucrose gradient fractions was run on a 10\% SDS-PAGE and transferred (Thermo Scientific Owl Hep-1) to PVDF membrane (BioRad Immun-Blot PVDF no. 162-0177). The membrane was incubated with anti-LtrA primary antibody (Covance). The secondary, peroxidase-labeled anti-rabbit, antibody, and detection reagents were used according to manufacturer's protocol (GE Healthcare Amersham ECL Western Blotting Analysis System RPN2108).

\section{Ribosome purification}

Cell growth and preparation of IL1403 was performed as for the intein-based construct, with an additional treatment of DNase I for $30 \mathrm{~min}$ after sonication. The cleared lysate was loaded onto a $5 \%-40 \%$ sucrose cushion $(20 \mathrm{mM}$ Tris at $\mathrm{pH} 7.5,50 \mathrm{mM}$ $\mathrm{NH}_{4} \mathrm{C} 1,0.5 \mathrm{mM}$ EDTA, $6 \mathrm{mM} \beta \mathrm{me}$, and $10 \mathrm{mM} \mathrm{MgC1}_{2}$ for the $5 \%$ buffer and the same, but with $500 \mathrm{mM} \mathrm{NH}_{4} \mathrm{C} 1$ for the $40 \%$ buffer) and run in an SW28 rotor (Beckman Coulter) at 28,000 RPM for $26 \mathrm{~h}$. The pellets were resuspended in buffer for $70 \mathrm{~S}$ preparation (50 $\mathrm{mM} \mathrm{NH}_{4} \mathrm{Cl}, 10 \mathrm{mM} \mathrm{MgCl}_{2}, 20 \mathrm{mM}$ Tris at $\mathrm{pH}$ 7.5, 0.5 mM EDTA, and $6 \mathrm{mM} \beta$-mercaptoethanol) or for $30 \mathrm{~S} / 50 \mathrm{~S}$ preparation $(60 \mathrm{mM}$ $\mathrm{NH}_{4} \mathrm{Cl}, 10 \mathrm{mM}$ Tris at $\mathrm{pH}$ 7.5, $0.1 \mathrm{mM}$ EDTA, and $2 \mathrm{mM} \beta \mathrm{me}$ ). For $70 \mathrm{~S}$ ribosomes, a $10 \%-40 \%$ sucrose gradient in $20 \mathrm{mM}$ Tris $(\mathrm{pH}$
8.0), $10 \mathrm{mM} \mathrm{MgC1}_{2}, 100 \mathrm{mM} \mathrm{NH}_{4} \mathrm{Cl}, 0.5 \mathrm{mM}$ EDTA, and $6 \mathrm{mM}$ $\beta \mathrm{me}$ was then run using an SW41 rotor (Beckman Coulter) at 41,000 RPM for 5 h. For 30S/50S ribosomes, a 15\%-30\% sucrose gradient in $60 \mathrm{mM} \mathrm{NH}_{4} \mathrm{Cl}, 10 \mathrm{mM}$ Tris ( $\mathrm{pH}$ 7.5), $0.1 \mathrm{mM}$ EDTA, and $2 \mathrm{mM} \beta \mathrm{me}$ was run using an SW41 rotor at 41,000 RPM for $18 \mathrm{~h}$. The gradients were fractionated and quantitated, and appropriate fractions were combined and concentrated using Amicon Ultra- $0.5 \mathrm{~mL}$ centrifugal filter units (MW-CO:10 kDa, Millipore).

\section{Ribosome binding}

Labeled in vitro transcript of $+\mathrm{A}$ intron RNA (75 nM) containing the 902 -nt intron with $27 \mathrm{nt} 5^{\prime}$ and $26 \mathrm{nt} 3^{\prime}$ was synthesized in vitro using the Megascript T7 transcription kit (Ambion no. AM1334) with a PCR template generated from plasmid $\mathrm{p}+\mathrm{A} / \mathrm{L}$ trA using IDT1561 and IDT1562 and ${ }^{32} \mathrm{P}$ a-UTP. The transcript was purified from a $5 \%$ denaturing acrylamide gel and renatured by heating for 1 min at $50^{\circ} \mathrm{C}$ in $0.5 \mathrm{M} \mathrm{NH}_{4} \mathrm{Cl}, 5 \mathrm{mM} \mathrm{MgCl}_{2}, 40 \mathrm{mM}$ Tris- $\mathrm{HCl}$ ( $\mathrm{pH}$ 7.5), and 0.5 units/ $\mu \mathrm{L}$ RNasin and cooling for $20 \mathrm{~min}$ at room temperature. The intron RNA and $30 S$ or $70 S$ ribosomes were mixed in a $20 \mu \mathrm{L}$ volume in binding buffer $(40 \mathrm{mM}$ Tris- $\mathrm{HCl}$ at $\mathrm{pH} 7.5,400$ $\mathrm{mM} \mathrm{NaCl}, 5 \mathrm{mM} \mathrm{MgCl}_{2}$, and $0.1 \% \mathrm{NP}-40$ ) alongside a control reaction with no ribosomes. Reactions were incubated for $2-3 \mathrm{~h}$ at room temperature and separated on a native $1.5 \%$ Agarose gel in $0.5 \times \mathrm{TBE}$ buffer overnight at $4^{\circ} \mathrm{C}$ at $59 \mathrm{~V}$. The gel was fixed in $10 \%$ acetic acid and $10 \%$ methanol, blotted dry, exposed to a phosphor screen, and developed on a Typhoon Trio (Amersham Biosciences). The amount of binding was determined by measuring shifted RNA relative to total RNA for each lane, using ImageQuant 5.2 software (Molecular Dynamics). To test specificity of the interaction between the in vitro transcript of the $+\mathrm{A}$ intron RNA and $30 \mathrm{~S}$ and $70 \mathrm{~S}$ ribosomes, RNA binding experiments were performed as described above with competitor RNAs. Nonspecific RNA competitors yeast tRNA ${ }^{\text {Phe }}$ (Sigma) and polyA (Life Technologies) were added at five- and 10-fold excess, while a specific competitor, unlabeled in vitro intron RNA transcript, was added at fivefold excess. RNA concentration used was $75 \mathrm{nM}$, whereas $30 \mathrm{~S}$ and $70 \mathrm{~S}$ ribosomes were used at 200 and $100 \mathrm{nM}$, respectively.

\section{DNA binding (EMSA) and reverse splicing assays}

Each DNA oligonucleotide $(10 \mathrm{pmol})$ was labeled at the $5^{\prime}$ end with $\gamma^{32} \mathrm{P}$-ATP using T4 polynucleotide kinase for $1 \mathrm{~h}$ at $37^{\circ} \mathrm{C}$ and then diluted to $50 \mu \mathrm{L}$ with nuclease-free water. Excess dNTP was removed on Sephadex G-25 column (GE Healthcare). To form DNA duplex, equal volumes of labeled top and bottom strand DNAs were mixed, heated for $3 \mathrm{~min}$ at $90^{\circ} \mathrm{C}$, and cooled slowly to $25^{\circ} \mathrm{C}$. For reverse splicing, $1 \mu \mathrm{L}$ of labeled DNA duplex was mixed with concentrated sucrose gradient fractions from a + A RNP purification $(3 \mu \mathrm{L}$ individual fractions or $1 \mu \mathrm{L}$ combined fractions $12-14$ or 20-23) and reverse splicing buffer $\left(10 \mathrm{mM} \mathrm{KCl}, 10 \mathrm{mM} \mathrm{MgCl}_{2}, 50 \mathrm{mM}\right.$ Tris- $\mathrm{HCl}$ at pH 7.5, $5 \mathrm{mM}$ DTT, $0.01 \% \mathrm{NP}-40$, and $0.01 \%$ Tween-20) to a total volume of $10 \mu \mathrm{L}$. After incubation for $50 \mathrm{~min}$ at $37^{\circ} \mathrm{C}$, the reaction products were resolved on a $4 \%$ native and a $10 \% 7 \mathrm{M}$ urea polyacrylamide gel for RNP-DNA binding and reverse splicing assay, respectively. Quantitation was with Image-Quant 5.0 software (Molecular Dynamics). For EMSA, signal values of gel shifts were collected, and activity was calculated relative to fraction 12 or 
fraction 12-14. For reverse splicing activity, the signal of integration products or cleavage products was expressed relative to the same fractions as for EMSA.

\section{DMS footprinting}

The methods for DMS treatment, reverse transcription, and PAGE sequencing are according to the methods previously described (Tijerina et al. 2007). The RNP and RNP+30S complexes were suspended in a folding solution $(20 \mathrm{mM}$ Tris $\mathrm{HCl}$ at $\mathrm{pH}$ 7.5, $200 \mathrm{mM}$ $\mathrm{KCl}, 5 \mathrm{mM} \mathrm{MgCl}$ ), and $10 \mu \mathrm{L}$ was added to $1 \mu \mathrm{L}$ of diluted DMS (1:5 in ethanol) at $50 \mathrm{ng} / \mu \mathrm{L}$ RNA and incubated for $2 \mathrm{~min}$ at room temperature. The reaction was halted by adding $475 \mu \mathrm{L}$ of quench solution ( $30 \% \mathrm{v} / \mathrm{v} \beta$-mercaptoethanol, $0.3 \mathrm{M}$ sodium acetate). Carrier RNA $(10 \mu \mathrm{g})$ was added to facilitate precipitation, by the addition of $1 \mathrm{~mL}$ of EtOH. After phenol extraction, the RNA was subjected to reverse transcription (steps 15-37) (Tijerina et al. 2007 ), except that $\sim 0.05-0.08$ pmol of RNA was used for each sequencing and reverse transcription reaction (step 15), and the RNA-primer annealing was at $98^{\circ} \mathrm{C}$, instead of $85^{\circ} \mathrm{C}$ (step 16). The annealed RNA was incubated for $5 \mathrm{~min}$ at $50^{\circ} \mathrm{C}$ to promote primer annealing, and reverse transcription was conducted at $50^{\circ}$ $\mathrm{C}$ instead of $42^{\circ} \mathrm{C}$ to lessen the effects of secondary structure (step 24). The ${ }^{32} \mathrm{P}$-labeled primers used to footprint LtrB are described in Supplemental Table 2. Gel images were captured on phosphorimaging screens and developed in a Storm 860 Molecular Imager (GMI). Potential bands of interest were identified visually and through SAFA (Semi-Autonomous Footprinting Analysis) (Das et al. 2005). The intensity of these bands were analyzed using TotalLab Quant version 12.2. The intensity of a given band was divided by the intensity of the fully extended product to give the fractional intensity of the band. Samples that showed ratios greater than 1.5 between free RNA and RNA complexed with 30 S particles were taken to be significant.

\section{RNase E cleavage assays and cleavage site mapping}

Labeled +A intron RNA transcript was prepared and renatured as described above in the Ribosome Binding section. For cleavage, $200 \mathrm{ng}$ of renatured transcript was incubated with $30 \mathrm{~S}$ or $70 \mathrm{~S}$ ribosomes at room temperature in cleavage buffer $(25 \mathrm{mM}$ Tris at $\mathrm{pH} 7.5,50$ $\mathrm{mM} \mathrm{NaCl}, 50 \mathrm{mM} \mathrm{KCl}, 10 \mathrm{mM} \mathrm{MgCl}, 1 \mathrm{mM}$ DTT, and 0.5 units/ $\mu \mathrm{L}$ RNasin) for $30 \mathrm{~min}$. RNase $\mathrm{E}$ was added, and reactions were incubated for $30 \mathrm{~min}$ at $37^{\circ} \mathrm{C}$. Gel loading dye was added, and the samples were loaded onto a $5 \%$ denaturing acrylamide gel. Labeled ФX174/Hinfl DNA Marker (Promega) was used as a size marker. Gels were dried, exposed to phosphor screen, developed on a Typhoon Trio, and analyzed using Image Quant 5.2 software to determine the percentage of substrate remaining in each lane under each condition. The average substrate remaining under each condition, including standard deviation, was plotted using Microsoft Excel.

To map the RNase E cleavage sites, primer extension analysis of the RNAse E/ribosome treated samples was done using oligonucleotides spanning the entire intron (Supplemental Table 2). Unlabeled in vitro transcripts of $+\mathrm{A}$ intron were renatured and treated as described above. Then, samples were extracted with phenol/chloroform and ethanol precipitated. Primer extension analysis of these samples was done using the Promega Primer Extension System-
AMV Reverse Transcriptase (E3030), and samples were run on a $5 \%$ denaturing acrylamide gel next to $\mathrm{G}, \mathrm{A}, \mathrm{T}, \mathrm{C}$ ladders generated using $\mathrm{p}+\mathrm{A}$ and a USB Thermo Sequenase Cycle Sequencing Kit (78500).

\section{RTP assay}

Group II intron donor pET-TORF/RIG was transformed into $\mathrm{CaCl}_{2}$ competent cells for strains MC1061(DE3), MC1061(DE3) rne::Tn5, MC1061(DE3) $\Delta r b f A$, MC1061(DE3) rne::Tn5 $\Delta r b f A$. Transformants were selected on $\mathrm{LB}$ plates with Ampicillin $100 \mu \mathrm{g} / \mathrm{mL}$ at $37^{\circ} \mathrm{C}$ overnight. Transformants were used to inoculate $500 \mu \mathrm{L}$ of LB media containing Ampicillin $100 \mu \mathrm{g} / \mathrm{mL}$, and were grown in 96-deep-well plates (Eppendorf \#951033405) overnight at $37^{\circ} \mathrm{C}$ shaking at 300 RPM. Cultures were diluted 1 in 100 into $1 \mathrm{~mL}$ of selective medium and grown to an $\mathrm{OD}_{600}$ of $\sim 0.2$ in 96 -deep-well plates at $37^{\circ} \mathrm{C}$, with shaking at 300 RPM. Group II intron expression was induced with $100 \mu \mathrm{M}$ IPTG for $3 \mathrm{~h}$. Culture was diluted and plated on LB to determine total cell count and on LB with Kanamycin $40 \mu \mathrm{g} / \mathrm{mL}$ to select for RTP events. RTP frequency was calculated as number of events per cell.

\section{SUPPLEMENTAL MATERIAL}

Supplemental material is available for this article.

\section{ACKNOWLEDGMENTS}

Work in our laboratories is supported by NIH grants GM39422 and GM448944 to M.B., funds from the Welch Foundation (F-1756) and a DTRA Young Investigator Award to L.M.C., and funds from the Welch Foundation to R.R. (F-1563). We thank Rebecca McCarthy and Matthew Stanger for their help in preparing the manuscript and figures, respectively. We thank John Dansereau (Wadsworth Center) for help with trouble shooting data in Figure 1. We thank Dr. Ben Luisi (Cambridge University) for preparations of RNase E and the D303R mutant enzyme and Dr. Masayori Inouye (Rutgers University) for $r b f A$ mutants.

Received March 11, 2013; accepted July 26, 2013.

\section{REFERENCES}

Barrera A, Pan T. 2004. Interaction of the Bacillus subtilis RNase P with the 30 S ribosomal subunit. RNA 10: 482-492.

Beauregard A, Chalamcharla VR, Piazza CL, Belfort M, Coros CJ. 2006. Bipolar localization of the group II intron Ll.LtrB is maintained in Escherichia coli deficient in nucleoid condensation, chromosome partitioning and DNA replication. Mol Microbiol 62: 709-722.

Beauregard A, Curcio MJ, Belfort M. 2008. The take and give between retrotransposable elements and their hosts. Annu Rev Genet 42: 587-617.

Belfort M, Derbyshire V, Cousineau B, Lambowitz A. 2002. Mobile introns: Pathways and proteins. In Mobile DNA II (ed. Craig N, et al.), pp. 761-783. ASM Press, Washington, DC.

Bonen L, Vogel J. 2001. The ins and outs of group II introns. Trends Genet 17: 322-331.

Carpousis AJ. 2007. The RNA degradosome of Escherichia coli: An mRNA-degrading machine assembled on RNase E. Annu Rev Microbiol 61: 71-87. 
Coros CJ, Landthaler M, Piazza CL, Beauregard A, Esposito D, Perutka J, Lambowitz AM, Belfort M. 2005. Retrotransposition strategies of the Lactococcus lactis Ll.LtrB group II intron are dictated by host identity and cellular environment. Mol Microbiol 56: 509-524.

Coros CJ, Piazza CL, Chalamcharla VR, Belfort M. 2008. A mutant screen reveals RNase $\mathrm{E}$ as a silencer of group II intron retromobility in Escherichia coli. RNA 14: 2634-2644.

Coros CJ, Piazza CL, Chalamcharla VR, Smith D, Belfort M. 2009. Global regulators orchestrate group II intron retromobility. Mol Cell 34: 250-256.

Cousineau B, Smith D, Lawrence-Cavanagh S, Mueller JE, Yang J, Mills D, Manias D, Dunny G, Lambowitz AM, Belfort M. 1998. Retrohoming of a bacterial group II intron: Mobility via complete reverse splicing, independent of homologous DNA recombination. Cell 94: 451-462.

Cui X, Matsuura M, Wang Q, Ma H, Lambowitz AM. 2004. A group II intron-encoded maturase functions preferentially in cis and requires both the reverse transcriptase and X domains to promote RNA splicing. J Mol Biol 340: 211-231.

Dai L, Toor N, Olson R, Keepign A, Zimmerly S. 2003. Database for mobile group II introns. Nucleic Acids Res 31: 424-426.

Dai L, Chai D, Gu SQ, Gabel J, Noskov SY, Blocker FJ, Lambowitz AM, Zimmerly S. 2008. A three-dimensional model of a group II intron RNA and its interaction with the intron-encoded reverse transcriptase. Mol Cell 30: 472-485.

Das R, Laederach A, Pearlman SM, Herschlag D, Altman RB. 2005. SAFA: Semi-automated footprinting analysis software for highthroughput quantification of nucleic acid footprinting experiments. RNA 11: 344-354.

Datsenko KA, Wanner BL. 2000. One-step inactivation of chromosomal genes in Escherichia coli K-12 using PCR products. Proc Natl Acad Sci 97: 6640-6645.

Dreyfus M. 2009. Killer and protective ribosomes. Prog Mol Biol Transl Sci 85: 423-466.

Galej WP, Oubridge C, Newman AJ, Nagai K. 2013. Crystal structure of Prp8 reveals active site cavity of the spliceosome. Nature 493: 638-643.

Horton RM, Cai Z, Ho SN, Pease LR. 1990. Gene splicing by overlap extension: Tailor-made genes using the polymerase chain reaction. Biotechniques 8: 528-536.

Huang HR, Chao MY, Armstrong B, Wang Y, Lambowitz AM, Perlman PS. 2003. The DIVa maturase binding site in the yeast group II intron aI2 is essential for intron homing but not for in vivo splicing. Mol Cell Biol 23: 8809-8819.

Huang T, Shaikh T, Gupta K, Contreras-Martin L, Grassucci RA, Van Duyne G, Frank J, Belfort M. 2011. The group II intron ribonucleoprotein precursor is a large, loosely packed structure. Nucleic Acids Res 7: 2845-2854.

Inoue K, Alsina J, Chen J, Inouye M. 2003. Suppression of defective ribosome assembly in a $r b f A$ deletion mutant by overexpression of Era, an essential GTPase in Escherichia coli. Mol Microbiol 48: $1005-1016$.

Jackson S, Cannone J, Lee J, Gutell R, Woodson S. 2002. Distribution of rRNA introns in the three-dimensional structure of the ribosome. $J$ Mol Biol 323: 35-52.

Lambowitz AM, Belfort M. 1993. Introns as mobile genetic elements. Annu Rev Biochem 62: 587-622.

Lambowitz AM, Zimmerly S. 2011. Group II introns: Mobile ribozymes that invade DNA. Cold Spring Harb Perspect Biol 3: a003616.

Marintchev A, Wagner G. 2004. Translation initiation: Structures, mechanisms and evolution. Q Rev Biophys 37: 197-284.
Matsuura M, Noah JW, Lambowitz AM. 2001. Mechanism of maturasepromoted group II intron splicing. EMBO J 20: 7259-7270.

Mazauric MH, Leroy JL, Visscher K, Yoshizawa S, Fourmy D. 2009. Footprinting analysis of BWYV pseudoknot-ribosome complexes. RNA 15: 1775-1786.

Michel F, Ferat JL. 1995. Structure and activities of group II introns. Annu Rev Biochem 64: 435-461.

Mills DA, Manias DA, McKay LL, Dunny GM. 1997. Homing of a group II intron from Lactococcus lactis subsp. lactis ML3. J Bacteriol 179: 6107-6111.

Nikolcheva T, Woodson SA. 1997. Association of a group I intron with its splice junction in $50 \mathrm{~S}$ ribosomes: Implications for intron toxicity. RNA 3: 1016-1027.

Pyle AM, Lambowitz AM. 2006. Group II introns: Ribozymes that splice RNA and invade DNA. In The RNA World, pp. 469-505. Cold Spring Harbor Laboratory Press, Cold Spring Harbor, NY.

Pyle AM, Fedorova O, Waldsich C. 2007. Folding of group II introns: A model system for large, multidomain RNAs? Trends Biochem Sci 32: $138-145$.

Qin PZ, Pyle AM. 1997. Stopped-flow fluorescence spectroscopy of a group II intron ribozyme reveals that domain 1 is an independent folding unit with a requirement for specific $\mathrm{Mg}^{2+}$ ions in the tertiary structure. Biochemistry 36: 4718-4730.

Rigaut G, Shevchenko A, Rutz B, Wilm M, Mann M, Seraphin B. 1999. A generic protein purification method for protein complex characterization and proteome exploration. Nat Biotechnol 17: 10301032.

Saldanha R, Chen B, Wank H, Matsuura M, Edwards J, Lambowitz AM. 1999. RNA and protein catalysis in group II intron splicing and mobility reactions using purified components. Biochemistry 38: 90699083.

Singh RN, Saldanha RJ, D’Souza LM, Lambowitz AM. 2002. Binding of a group II intron-encoded reverse transcriptase/maturase to its high affinity intron RNA binding site involves sequence-specific recognition and autoregulates translation. J Mol Biol 318: 287-303.

Smith D, Zhong J, Matsuura M, Lambowitz AM, Belfort M. 2005. Recruitment of host functions suggests a repair pathway for late steps in group II intron retrohoming. Genes Dev 19: 2477-2487.

Tamura M, Moore CJ, Cohen SN. 2013. Nutrient dependence of RNase E essentiality in Escherichia coli. J Bacteriol 195: 1133-1141.

Tijerina P, Mohr S, Russell R. 2007. DMS footprinting of structured RNAs and RNA-protein complexes. Nat Protoc 2: 2608-2623.

Toro N, Jimenez-Zurdo JI, Garcia-Rodriguez FM. 2007. Bacterial group II introns: Not just splicing. FEMS Microbiol Rev 31: 342-358.

Tsai YC, Du D, Dominguez-Malfavon L, Dimastrogiovanni D, Cross J, Callaghan AJ, Garcia-Mena J, Luisi BF. 2012. Recognition of the 70S ribosome and polysome by the RNA degradosome in Escherichia coli. Nucleic Acids Res 40: 10417-10431.

Wank H, SanFilippo J, Singh RN, Matsuura M, Lambowitz AM. 1999. A reverse-transcriptase/maturase promotes splicing by binding at its own coding segment in a group II intron RNA. Mol Cell 4: 239250.

Xia B, Ke H, Shinde U, Inouye M. 2003. The role of RbfA in $16 \mathrm{~S}$ rRNA processing and cell growth at low temperature in Escherichia coli. J Mol Biol 332: 575-584.

Yao J, Truong DM, Lambowitz AM. 2013. Genetic and biochemical assays reveal a key role for replication restart proteins in group II intron retrohoming. PLoS Genet 9: e1003469.

Zhou L, Manias DA, Dunny GM. 2000. Regulation of intron function: Efficient splicing in vivo of a bacterial group II intron requires a functional promoter within the intron. Mol Microbiol 37: 639-651. 

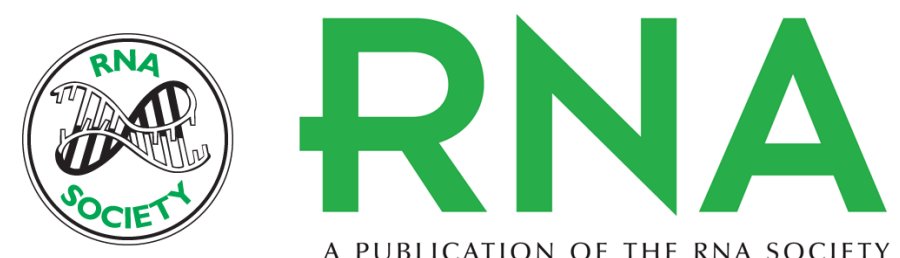

A PUBLICATION OF THE RNA SOCIETY

\section{Group II intron-ribosome association protects intron RNA from degradation}

Lydia M. Contreras, Tao Huang, Carol Lyn Piazza, et al.

RNA 2013 19: 1497-1509 originally published online September 17, 2013

Access the most recent version at doi:10.1261/rna.039073.113

\section{Supplemental http://rnajournal.cshlp.org/content/suppl/2013/08/08/rna.039073.113.DC1 \\ Material}

References This article cites 43 articles, 12 of which can be accessed free at: http://rnajournal.cshlp.org/content/19/11/1497.full.html\#ref-list-1

Creative This article is distributed exclusively by the RNA Society for the first 12 months after the Commons

License full-issue publication date (see http://rnajournal.cshlp.org/site/misc/terms.xhtml). After 12 months, it is available under a Creative Commons License (Attribution-NonCommercial 3.0 Unported), as described at http://creativecommons.org/licenses/by-nc/3.0/. Email Alerting $\begin{aligned} & \text { Receive free email alerts when new articles cite this article - sign up in the box at the } \\ & \text { Service }\end{aligned}$ top right corner of the article or click here. 